\title{
THE CRIMINAL LAW RESPONSE TO THE MIGRANT AND REFUGEE CRISIS
}

\author{
Nikola Tupanceski, PhD, \\ Faculty of Law, Institute for Criminal Law \\ E-mail: tupanceski@yahoo.com \\ Aleksandra Deanoska, PhD, \\ Faculty of Law, Institute for Criminal Law \\ E-mail: aleksandra.deanoska@gmail.com
}

\section{Abstract}

As the subject of elaboration in this paper, the authors refer to the phenomenon of migration - phenomenon that always raised special interest in scientific circles, but recent years is particularly topical and actual question. Migration may be reviewed in a form of several manifestations like: voluntary (mainly economic) and forced migration caused by persecution, armed conflicts, war or other factors. The issue of refugees, asylum seekers and internal displaced persons is also particularly addressed and it is a special challenge from phenomenological aspect.

The authors also elaborate the international corpus of human rights instruments for the protection of migrants and refugees, starting from the Universal Declaration of Human Rights, the Convention on the Status of Refugees, the Convention on migrations in abusive conditions and the promotion of equal opportunities and treatment to migrant workers, International Convention for the protection of the rights of all migrant workers and members of their families, the Protocol against the Smuggling of Migrants by Land, Sea and Air, supplementing the United Nations Convention against Transnational organized Crime etc.

As a result of the international efforts in respect of the protection of the rights of refugees and migrants, and especially taking into consideration the migrant and 


\section{Seccuriatity}

refugee wave that took place globally, but also in the Republic of Macedonia as transiting country recent years, special attention is paid to the issue of the Criminal Law response.

In this sense, the incriminations of the Criminal Code are elaborated: Art. 418b, smuggling of migrants art.418-v, organizing a group and instigating the perpetration of such offences, art. 418-d, abuse of the visa-free regime with the member states of the European Union and of the Schengen Agreement, as well as the criminal offenses of the Law on foreigners. Authors also give reviews to the Law on asylum and temporary protection and general review of our legislation with the aim to provide elaboration on the question whether the criminal law response is appropriate.

Keywords: migration, migrant, smuggling of migrants, illegal immigration

\section{Introduction}

The migration and refugee issues are tremendously actual the recent years. Migration is not a new phenomenon; in fact it is old as humanity itself. Unlike the ancient period when it was perceived as an inherent segment of Greek colonization and Roman expansion, in recent history (18-19 century) it is transformed as the forced relocation of slaves from West Africa to America, and today again, the migration phenomenon, retaining and intensifying the continued negative context, has an extremely serious impact in shaping the world, thereby manifesting its complex social, cultural, political and legal level.

In this respect, in the theory and in the international documents we can find the basic classification of this phenomenon. Its political connotation prevails over it numerical value (Koser, 2007). Unlike voluntary, which mostly deals with economic migrants, forced migration is connected to reasons different from those of "a better existence" - such as the conflicts, persecution or environmental factors. In this context particular attention should be paid on the organized nature of this form of criminal activity. The migration factors are different, mainly known as push or pull factors (Bales, 1999, also see 0'Connel, 2001).

With the beginning of the "Arab Spring" in late 2010, the international scene is particularly actualized with the immigrant issue of refugees, asylum seekers and 
internally displaced persons. According to the United Nations High Commissioner for Refugees (UNHCR) from 2014, the number of these people in the world exceeds 50 million.

In this regard, in the recent period there is a tendency to restrict the use of the term "illegal immigration" to cases of smuggling of migrants and trafficking. Argumentum a fortiori, there are claims for abandoning of the term "illegal immigrant" and instead use the terms "irregular" or "undocumented" immigrant.

\section{The international human rights instruments on migration issues}

Given the fact that the immigration phenomenon may pose a serious threat to internal state security, public policy, public health and international relations between states, the statement that "illegal immigration" is a problem of global importance is not even slightly exaggerating! From there arise the efforts of the international community to prevent illegal cross-border movement, namely to find ways for its prevention.

The international rules for the protection of migrants in the modern sense of the word, may be recorded as early as 1948 Universal Declaration of Human Rights which defines the right "to leave the country." Otherwise, the huge number of international documents regulating this matter specifically implies the prevention and repression of crime associated with "illegal immigration". For example, the Convention on the Status of Refugees of 1951, in Art. 31 contains a prohibition that contracting states impose penalties on refugees who come from a territory where their life or freedom is threatened for illegal entry or residence, provided that they apply without delay to the authorities and show good cause for their illegal entry or stay. From this point of view, very important is the prohibition on their expulsion or return provided for in Art. 33, according to which any contracting state shall not expel or return a refugee in any manner whatsoever to the frontiers of territories where his life or freedom would be threatened on account of his race, religion, nationality, membership of a particular social group or political opinion.

The Convention Concerning Migrations in Abusive Conditions and the Promotion of Equality of Opportunity and Treatment of Migrant Workers of 1975, places an obligation on member states to adopt all necessary measures to prevent the secret movements of migrants for employment and illegal employment of migrants, and 


\section{Seccurity}

against the organizers of illicit or clandestine movements of migrants for employment by departure, arrival or transit its territory, and against those who employ workers who have immigrated in illegal conditions. Provided that resided legally in the territory for the purposes of employment, the migrant worker shall not be deemed to be illegal or irregular in situation by the mere fact of losing his job, which in itself means the withdrawal of his authorization of residence or, as case may be, work permit. Accordingly, he shall enjoy equal treatment with the citizens, particularly in terms of guarantees of security of employment, the provision of alternative employment, work and retraining.

The International Convention for the Protection of the Rights of All Migrant Workers and Members of Their Families of 1990 provides that states shall cooperate when necessary to adopt measures for proper return of migrant workers and members of their families in the country of origin when they decide to return or upon expiry of their residence or employment permit or when they have illegal status in the country of employment (Art. 67). In the next article of the Convention is proclaimed the obligation to member states, including the state of transit, to cooperate to prevent and eliminate illegal or irregular movements and employment of migrant workers with irregular status. Measures taken for this purpose under the jurisdiction of each country concerned should include: appropriate measures against the dissemination of misleading information on emigration and immigration; measures to detect and eradicate illegal and unreported movement of migrant workers and members of their families and to impose effective sanctions on persons, groups or entities which organize, conduct or assist with the development and implementation of such movements and measures to impose effective sanctions on persons, groups or entities which use violence, threats or intimidation against migrant workers and members of their families who have illegal status. States of employment shall take all adequate and effective measures to eliminate employment of migrant workers in their territory who have illegal status, including where appropriate, sanctions on employers of such workers.

The most important document that explicitly deals with the issue of "illegal immigration" is the Protocol against the Smuggling of Migrants by Land, Sea and Air, supplementing the United Nations Convention against Transnational Organized Crime (Palermo Convention) of 2000. It should be particularly noted that it operates and defines the term "smuggling of migrants" and "illegal entry". Under this Protocol, the 
term "smuggling of migrants" means providing illegal entry i.e. crossing borders without respecting the necessary requirements for legal entry into a country of a person in a Member State where that person is not a citizen or resident in order directly or indirectly to obtain financial or other material benefit .

Although the Protocol establishes an obligation for each state party to criminalize acts of smuggling of migrants; acts committed for the purpose of enabling the smuggling of migrants; manufacture, procurement, having or providing false travel or identity document; and by enabling the person without citizenship or permanent resident to remain in the respective country without fulfilling the necessary conditions for staying in the country or other illegal means; this protocol clearly establishes that migrants who were subject to such actions will not be subjected to criminal prosecution. Furthermore, the Protocol provides that any attempt to commit any of the foregoing acts and complicity, organizing or directing others to commit such acts should be punishable. As aggravating circumstances should be considered the endangering or the possibility to endanger the lives or safety of the migrants and those who undertake inhuman or degrading treatment, including exploitation of such migrants.

In order to prevent and suppress the smuggling of migrants by sea, the Protocol provides for an obligation for Member States to cooperate to the greatest extent possible, including the exchange of relevant data in accordance with the international maritime law, and stipulates adequate measures that States should undertake. Furthermore, without affecting the international rules on free flow of people, state parties, to the greatest extent possible, should reinforce that border control is needed to prevent and detect the smuggling of migrants, and to adopt legislative or other appropriate measures for, as far as possible, to prevent the use of vehicles that run commercial carriers, to commit the offenses subject to the Protocol.

\section{The Criminal legislation in respect of "illegal immigration" in Macedonia}

As international basis in designing the legal framework for the incriminations related to "illegal immigration", most European countries have taken directions from the Protocol against the Smuggling of Migrants by Land, Sea and Air, supplementing the UN Convention against Transnational Organized Crime and UN documents from 2010, Model law against smuggling of migrants. In this context, it should be pointed 
out that the latter act, in the second chapter titled "Basic offenses" explicitly talks about the ontology of incriminations associated with this form of criminality.

Republic of Macedonia, especially taking into account Article 6 of the Protocol, which established basic criteria for criminalization of unlawful activities related to the smuggling of migrants, provides a set of incriminations that regulate the criminal context of this matter, namely, in two different laws (the Criminal Code of Macedonia and the Law on Foreigners) there are several provisions.

In that context, chapter thirty four of the Criminal Code of the Republic of Macedonia, entitled "Crimes against humanity and international law" covers three provisions relevant to this area: Art. 418-b "smuggling of migrants", Article 418-c "organizing a group and inciting the perpetration of acts of trafficking, trafficking in children and smuggling of migrants" and Article 418-e "abuse of the visa regime with the countries of the Union and the Schengen agreement".

When it comes to incriminations of this kind (legal description of the incrimination being with open character), in general, the object of protection is complex: on one hand, it covers the fundamental freedoms and rights of migrants, and on the other, the international regime on legal flow of migrants from one country to another. Not all legislators from different countries have approach similar or analogous as the Macedonian one. Some systematize these offences in the chapter on criminal offenses against public order - such as Serbia, Croatia, (Turkovic, Novoselec, 2013). Alluding to the conclusion that the primary object of protection is the public order, which in extensive sense identifies with the social or legal organization, the general security of citizens, the feeling of peace and unthreatened individual and common good. This determination once again verifies the complex character of the protected legal good, and that is the reason why these incriminations represent conglomerate of several subgroups focused on closer objects of protection.

The main incrimination is defined in Article 418 -b of the CCM titled "smuggling of migrants" and with its six paragraphs, it fully corresponds to the directions provided by Article 6 of the Protocol. Imprisonment of at least four years is prescribed for whom by force or serious threat that will attack the life or body, deceit, greed, abuse of position or using of the powerlessness of other illegally transfers migrants through the state border, and that produces, purchases or owns fake passport with such intention. Taking into account the quality of injustice provided in both sequences of this paragraph, we believe that one should not put a sign of "equality" 


\section{Seccurity}

between them in terms of punishment for the reason the second is just a predicate action regarding the realization of the criminal purpose. Of course, we have to keep in mind the overall penal policy relating to counterfeiting (official) documents. When it comes to the degree of harmonization with Article 6 of the Protocol, the Republic of Macedonia, unlike other countries, has fully provided for acceptance of all forms of execution.

"Illegal transfer" means the entry or exit of migrants in and from the country without the prescribed formalities for crossing the state border, border crossings or outside (if migrants are hidden in a vehicle outside the border crossing, if transmitted by wild roads through the border line). Passive subject of the offense is one or more migrants, which shall include persons who pass through the territory of another country in order to stay in the country (because of work, engaging in crime and other illegal activities, etc.). The action is completed with the transfer of one or more migrants across the state border. Subjective part of the crime contains intention or awareness that by force is made the transfer of persons that are about to acquire a status of migrants (Камбовски, 2011).

Mitigated form of the offence is contained in paragraph 2 and it consists of the recruitment, transportation, transfer, buying, selling, harboring or receipt of migrants. This form is punishable by imprisonment of one to five years. The action aims that the victim makes such a decision (recruitment) or to be taken after the decision has adopted or has been bought, sold, sheltered or accepted by the offender, who also assumed his consent.

Severe forms (paragraphs 3 to 5) are tied to several qualifying circumstances, endangering the life or health of migrant, treatment of migrant particularly degrading or cruelly, preventing migrant to use the rights granted by international law in perpetration of the offences; the crime against a minor and committing the crime by an official in performing his duty. The penalty is imprisonment for at least eight years, unless the perpetrator official in performing his duty, in which case the penalty is at least ten years.

The last paragraph of the provision (paragraph 6) provides for mandatory confiscation of objects and vehicles as objects of the crime (Article 100-a).

The analysis of the incrimination of Article 418-b shows that mostly it is compatible with the international standards. However, certain remarks can be pointed out. In this regard, we can comment the prescribed penalties. At least four years of 
imprisonment are prescribed for the basic form of the act, or at least eight or at least ten years for qualified forms - it seems that the severity of the lawmakers is draconian. Comparative experiences show that usually the basic offense sentence ranges up to three or five years while for qualified forms to five or ten years. Since the ultimate goal of the perpetrators of this criminal act is mostly financial gain, perhaps it would be part of the criminal policy fine to be prescribed and also confiscation of property and proceeds (Камбовски, Тупанчески, 2011).

Complementary to the previous provision is Article 418-c, which is about organizing a group and inciting the perpetration of acts of trafficking, trafficking in children and smuggling of migrants. This provision represents a special type of the offense criminal association (art.394). Imprisonment for at least eight years is prescribed for those who organized group, gang or other association for the execution of several crimes including the crime of smuggling migrants. Subject to this incrimination (paragraph 2) is a member of the group, gang or other association, and it is punishable by imprisonment of at least one year.

In Paragraph 3 is provided obligatory exemption from punishment of a member of the association in case of effective regret. Especially is incriminated (paragraph 4) the calling, encouraging or supporting the commission of these offenses. It is about forms of creation or strengthening of other, unspecified persons, the decision to commit the offenses, which does not incite any particular case: if the offender instigates another, or certain group of people, the pursuit of a particular case, it is punishable as an incitement. Supporting is a form of psychological assistance or encouragement of undetermined number of people to perform.

The set of the three provisions in the Criminal Code of Macedonia is completed with the provision of Art. 418-d: Abuse on visa-free regime with the Member States of the European Union and the Schengen Agreement which is actually a reflection of the visa regime that the Republic of Macedonia has established with the Member States. The offence is perpetrated the one who recruits, encourages, organizes, harbors or transports persons in a Member State of the European Union and the Schengen Agreement regarding the acquisition or exercise of social, economic or other rights contrary to European Union law, regulations of the European Union members and the Schengen agreement and international law. Sanctioned is also the case when the offender was obliged to know and could have known that the transfer is done in order to obtain or exercise of social, economic or other rights contrary to EU law, regulations 


\section{Securiagues}

of the Member States of the EU and the Schengen Agreement and the international right. For primary offense the penalty is imprisonment of at least four years, for the special form of imprisonment of one to five years, and for the qualified form of imprisonment for at least four years.

The second law, which stipulates the other two incriminations in respect with this matter, is the Law on Foreigners. Namely, in art. 148: Assisting foreigners in illegal entry and transit, with imprisonment of one year or with fine is punished helping illegal foreigner to enter the country or pass through the territory of the Republic of Macedonia contrary to the provisions stipulated in the Law on Foreigners. If the operator had intended to obtain illegal profit, it constitutes a more severe form of the crime that is punishable by imprisonment of at least three years. As aggravating circumstance will be considered the endangering the life of the foreigner, committing the crime in a group, gang or other association created to perform such work, so in these cases the perpetrator will be punished by imprisonment of at least eight years. The attempt of the offense is also punishable. A criminal liability for legal persons is also envisaged.

In the next article, 149, titled "Assisting foreigners in illegal residence", a prison sentence of three years is provided for a person who with the intention of acquiring unlawful proceeds for himself or another person will help the foreigner to stay in the Republic of Macedonia contrary to the legal provisions. The attempt is punishable and if the offender under paragraph 1 of this Article is a legal person, it shall be punished by a fine and will be imposed a temporary ban on performing certain activities or permanent ban on performing certain activities. Vehicles used for committing the crime shall be confiscated.

Both incriminations provided in this Law should be complementary but also consistent with the Macedonian Criminal Code in combating the phenomenon of smuggling migrants. In part perhaps this is an achieved goal - sanctioned is the attempt and criminal liability of legal persons is prescribed. But given the description of the legal basis of the acts, and the expected sanction, the real problem for any judge or prosecutor may represent the choice of legal provision under which the factual situation will be subsumed. In other words, helping foreigners in illegal entry and transit and aiding illegal foreigner in residence is a constitutive description of the incrimination of Article 418b, smuggling migrants. The problem is that if the Criminal Code provision is applied then the sentence will be at least four years if it is a basic form or from one to 


\section{Seccurity}

five years if it is proved that there is consent of the migrant. We remind that in severe forms, the legal minimum is eight or ten years. This means that identical legal situation applying one law means a penalty of at least four years in prison and according to the other (Law on foreigners) a sentence of one year or a fine. Taking into account the principle in dubio mitius then the more lenient law should be applied. But the crucial question is whether it is the case in practice.

In terms of suppression of the recently actual cases of illegal immigration, we should especially mark the recent activities of the Republic of Macedonia regarding the prevention of this phenomenon. The Law Amending the Law on Asylum, introduced changes in Article 16 in which it is regulated that foreigner on the border or inside the territory of the Republic of Macedonia may orally or in writing express the intention of submitting a request for asylum in front of a police officer of the Ministry of Interior.

The Police Officer records the foreigner who expressed intention and directs him within 72 hours to apply for asylum before the authorized official at the Department for Asylum in the Reception Center for Asylum Seekers.

If the foreigner does not fulfill the obligation or does not apply for asylum within 72 hours from the time of the declared intention, he will be proceeded in accordance with the regulations for foreigners.

In the new Article 16-a, it is determined the formal aspect that is submitting the application for asylum, elaborating all possible options. The adoption of these solutions was with the intention to overcome or prevent the problem of illegal migration, on the other hand to facilitate the potential asylum seekers access to the body conducting the procedure for recognition of the right of asylum.

This activity of Macedonia on preventive level means even greater affirmation of Article 16 of the Protocol that refers on measures of protection and assistance. It seems that this approach is needed given the fact that the last years the number of migrants (not only in Macedonia) receives a 'planetary' dimension and the social response proves to be inadequate.

\section{Conclusion}

The migration phenomenon is a complex matter of intense social, legal, cultural character. Lately, the negative context of migration is gaining on intensity and it results 
in social reaction on international and national level that seems insufficient in quality, but also inefficiently deals with this phenomenon. Verification of this thesis is the recent effort of the UN and the European Union that cannot reconcile their views on this 'burning' issue. Macedonia almost completely accepted and incorporated relevant international standards regarding the prevention and suppression of smuggling migrants.

In terms of criminal legislation we can put some remarks about the consistency of the legal framework composed of five incriminations in the two different laws that are abovementioned. It may be suggested that in future the existing set of criminal offenses should be revised aimed at harmonizing and reducing the possibility of different legal epilogue in identical situations. It should be also specifically indicated that the prescribed and pronounced penalties are draconian; particularly from comparative point of view Macedonia is a leader in the region in terms of the legal minimum for this type of offenses. At the end, we would like to point out that the focus should be put on prevention, having in mind that appropriate safeguards contribute to reduction of the crime rates.

\section{Bibliography:}

1. Bales, Kevin (1999). What predicts global trafficking? Paper presented on the international conference on UNICRI Verona, Italy

2. Koser, Khalid, "International Migration: A Very Short Introduction", Oxford University Press Inc, New York, 2007.

3. International Council on Human Rights Policy, "Irregular Migration, Migrant Smuggling and Human Rights: Towards Coherence", Imprimerie Gasser SA, Le Locle, Geneva.

4. European Union Agency for Fundamental Rights, "Handbook on European law relating to asylum, borders and immigration", Luxembourg: Publications Office of the European Union, Luxembourg, 2013.

5. Камбовски, В., Тупанчески, Н., „Казнено право - посебен дел“, Правен факултет "Јустинијан Први“ - Скопје, Скопје, 2011.

6. Камбовски, В. „Коментар на Кривичниот законик на Република Македонија - интегрален текст“, Матица, Скопје 2011. 
7. Keeler, L., Jyrkinen, M. (1999). Who's bying: The clients of prostitution. Helsinki, Finland

0' Connel Davidson, J. (2001) The sex exploiter. Theme paper for the Second World Congress Against Commercial Sexual Exploitation of Children. December 2001. Yokohama.

8. Turkovic, K., Novoselec, P., i drugi ${ }_{m}$ Kmentar kaznenog zakona I drugi izvori novoga hrvatskog kaznenog zakonodavstva, Narodne novine, Zagreb, travanj 2013.

9. Рајкел., Ф., Прирачник за транснацонален криминал и правда (Macedonian Edition), Датапонс, 2009.

10. Тупанчески, Н., Кривичен законик, интегрален текст, предговор, кратки објаснувања и регистар на поими, Скопје 2015.

11. Law on Foreigners, (Official Gazette of Republic of Macedonia, no. 35/2006, 66/2007, 117/2008, 92/2009, 156/2010, 158/2011, 84/2012, 13/2013, $147 / 2013,148 / 2015$ и 217/2015).

12. Law on Asylum and Temporary Protection (Official Gazette of Republic of Macedonia, no.. 49/2003, 66/ 2007, 142/2008, 146/2009, 166/2012, 101/2015, $152 / 2015,55 / 2016$ и 71/2016).

13. Universal Declaration of Human Rights (1948)

14. European Convention on Human Rights (1950)

15. Convention on the Status of Refugees (1951)

16. Convention on migrations in adverse conditions and promoting equal opportunities and treatment for migrant workers (1975)

17. International Convention for the Protection of the Rights of All Migrant Workers and Members of their Families (1990)

18. Protocol against the Smuggling of Migrants by Land, Sea and Air, supplementing the United Nations

Convention against Transnational Organized Crime (2000)

Model Law against the Smuggling of Migrants, United Nations Office on Drugs and Crime (UNODC), New York 2010.

19. http://www.gesetze-im-internet.de/englisch_stgb/englisch_stgb.html.

20. http://www.ohchr.org/Documents/HRBodies/CMW/Discussions/2014/PICUM_ CMW_DGD2014.pdf 
21. http://fra.europa.eu/sites/default/files/fra_uploads/2325-

Regularisation_paper-110912.pdf

22. http://esa.un.org/MigGMGProfiles/indicators/files/Macedonia.pdf

23. http://www.ifrc.org/PageFiles/89397/the\%20phenomenon\%20of\%20migration _TYPEFI_final_En.pdf

24. http://www.hss.de/fileadmin/migration/downloads/0802_IOM_Immigration.pd $\mathrm{f}$ 